\title{
Gaya Kepemimpinan Prof. Dr. Kh. Asep Saifuddin Chalim dalam Meningkatkan Motivasi Kerja Karyawan di Pesantren
}

\author{
Heriyono ${ }^{1}$, Rudolf Chrysoekamto ${ }^{2}$, Rezki Nurma Fitriah ${ }^{3}$, Ari Kartiko ${ }^{4}$ \\ ${ }^{1,2,3,4}$ Fakultas Tarbiyah, Istitut Pesantren KH abdul Chalim Pacet Mojokerto, Indonesia \\ heriyono.samengke57@gmail.com
}

Submitted: 15-02-2021 Revised : 16-03-2021 Accepted: 25-04-2021

\begin{abstract}
Pondok Pesantren Amanatul Ummah adalah lembaga pendidikan pondok pesantren yang terletak di bawah kaki gunung welirang, dan mempunyai beberapa lembaga, dianatranya MTS unggulan, MA unggulan, dan Perguruan Tinggi Unggulan. Rumusan masalah penelitian ini yaitu bagaimana gaya kepemipinan yang di terapkan oleh Kiai dan bentuk-bentuk motivasi apa saja yang diterapkan kepada karyawan di Pondok Pesantren Amanatul Ummah. Dengan jenis penelitian lepangan (field research) kualitatif, dengan subjek penelitian adalah Kiai, karyawan dan mitra kerja, pengumpulan data dengan teknik observasi, interview dan dokumentasi. Analisis data yang digunakan menurut Miles Huberman terdiri dari reduksi data, penyajian data dan penarikan kesimpulan, menggunakan teknik keabsahan data trianggulasi sumber data dan trianggulasi pengumpulan data, sehingga data yang dihasilkan akurat. Dari hasil penelitian ini bahwa Kiai Pondok Pesantren Amanatul Ummah tidak hanya menerapkan satu gaya kepemimpinan, melainkan di sisi tertentu juga menerapkan gaya kepemimpinan yang berbeda. Gaya kepemimpinan yang diterapkan dominan dengan kepemimpinan ototriter, meskipun di sisi lain beliau juga menerapkan kepemimpinan kharismatik. Hal tersebut diperkuat oleh fungsi kepemimpinan yang diterapkan Kiai Pondok Pesantren Amanatul Ummah. Serta bentuk-bentuk motivasi yang diberikan Kiai adalah menjalin hubungan personal yang baik kepada kayawan dan mitra kerja, perhatian kesejahtraan karyawan, memberikan reward kepada karyaawan yang berprestasi, berkumpul dan evaluasi bersama dengan karyawan.
\end{abstract}

Kata Kunci : Gaya Kepemimpinan, Motivasi Kerja, Pondok Pesantren

\begin{abstract}
The Amanatul Ummah Islamic Boarding School is an educational institution for Islamic boarding schools located at the foot of Mount Welirang, and has several institutions, including superior MTS, superior MA, and Superior Universities. The formulation of the research problem is how the leadership style is applied by Kiai and what forms of motivation are applied to employees at the Amanatul Ummah Islamic Boarding School. With this type of field research (field research) qualitative, with research subjects are Kiai, employees and partners, data collection by observation, interview and documentation techniques. The data analysis used according to Miles Huberman consists of data reduction, data presentation and conclusion drawing, using data validity techniques, triangulation of data sources and triangulation of data collection, so that the resulting data is accurate. From the results of this study, Kiai Pondok Pesantren Amantul Ummah does not only apply one leadership style, but also applies a different leadership style. The leadership style applied is dominant with authoritarian leadership, although on the other hand he also applies charismatic leadership. This is reinforced by the leadership function implemented by the Kiai Pondok Pesantren Amanatul Ummah. And the forms of motivation given by Kiai are establishing good personal relationships with employees and work partners, paying attention to employee welfare, giving rewards to employees who excel, gathering and evaluating together with employees.
\end{abstract}

Keywords: Leadership Style, Work Motivation, Islamic Boarding School. 
https://dx.doi.org/10.32678/tarbawi.vxx0x.xxxx

How to Cite Heriyono et al. (2021). Gaya Kepemimpinan Prof. Dr. Kh. Asep Saifuddin Chalim dalam Meningkatkan Motivasi Kerja Karyawan di Pesantren. Munaddhomab: Jurnal Manajemen Pendidikan Islam, Volume 2(I), 2021

\section{PENDAHULUAN}

Manusia adalah mahluk sosial yang tidak dapat hidup sendiri. Dalam hidup, manusia selalu berinteraksi dengan sesama serta lingkungan. Manusia hidup berkelompok baik dalam kelompok besar maupun berkelompok kecil. Manusia adalah mahluk Tuhan yang paling tinggi dibandingkan mahluk Tuhan yang lainnya. Manusia dianugrahi kemampuan untuk berfikir, kemampuan untuk memilah mana yang baik dan mana yang buruk. Dengan kelebihan itulah manusia seharusnya mampu mengelola lingkungan dengan baik (Arifin, 2014; Zuhairini, 1992).

Tidak hanya lingkungan yang perlu dikelola dengan baik, kehidupan sosial manusiapun perlu dikelola dengan baik. Untuk itulah dibutuhkan sumber daya manusia yang berkualitas. Sumber daya yang berjiwa pemimpin, paling tidak untuk memimpin dirinya sendiri. Dengan berjiwa pemimpin manusia akan dapat mengelola diri, kelompok dan lingkungan dengan baik. Khususnya dalam penanggulangan masalah yang relativ pelik dan sulit. Disinilah dituntut kearifan seseorang pemimpin dalam mengambil keputusan agar masalah dapat terselesaikan dengan baik (Krisbiyanto, 2019).

Kepemimpinan di Indonesia merupakan suatu Jenis kepemimpinan yang dijalankan oleh pejabat-pejabat pemerintahan. Itu merupakan satu Jenis kepemimpinan tertentu yaitu pemerintahan, bukannya kepemimpinan perusahaan, bukan pula kepemimpinan buruh, dan bukan juga kepemimpinan yang lain-lain (Danim, 2009). Berbicara tentang pemimpin dan kepemimpinan sebenarnya kita berbicara tentang sesuatu yang mempunyai latar belakang sejarah yang panjang dan jangkauan atau spektrum yang luas. Sejarah suatu bangsa dan negara pada dasarnya berkisar pada sejarah dari para pemimpin-pemimpinnya atau tokoh- tokohnya, baik dibidang politik, pemerintahan, keagamaan dan sebagainya (Devi \& Subiyantoro, 2021).

Pemimpin dapat mempengaruhi moral, kepuasan kerja, keamanan, kualitas kehidupan kerja dan terutama tingkat prestasi suatu organisasi. Kemampuan dan ketrampilan kepemimpinan dan motivasi dalam pengarahan adalah factor penting efektivitas manajer. Bila organisasi dapat mengidentifikasikan kualitas yang berhubungan dengan kepemimpinan, kemampuan untuk menyeleksi pemimpin-pemimpin yang efektif akan meningkat, bila organisasi dapat mengidentifikasikan perilaku dan teknik-teknik kepemimpinan efektif organisasi, berbagai perilaku dan teknik tersebut akan dapat dipelajari (Kartiko et al., 2020; Kartiko \& Azzukhrufi, 2019).

Analisis ilmiah tentang kepemimpinan berangkat dari pemusatan perhatian pemimpin itu sendiri. Theory sifat berkembang, pertama kali di Yunani Kuno dan Romawi yang beranggapan bahwa pemimpin itu dilahirkan, bukan diciptakan yang kemudian theory ini dikenal dengan "The Greatma Theory". Dalam perkembangannya, theory ini mendapat pengaruh dari aliran perilaku pemikir psikologi yang berpandangan bahwa sifat sifat kepemimpinan tidak seluruhnya dilahirkan akan tetapi juga dapat dicapai melalui pendidikan dan pengalaman (Ezzani \& Brooks, 2019).

Menurut Jamal (Yunus, 2009) mengemukakan bahwa kepemimpinan tidak sama dengan manajemen. Kepemimpinan membutuhkan suatu kemampuan yang lebih tinggi. Seseorang pemimpin yang menentukan ke mana arah suatu organisasi baik arah tujuan internal maupun eksteranal(Bahri \& Arafah, 2020). Pemimipin pula yang menyelaraskan aset dan keterampilan organisasi dengan kesempatan dan resiko yang dihadapkan oleh lingkungan. Pemimpin harus menjadi ahli strategi untuk menetapkan tujuan organisasi. Riset mengenai kepemimpinan belum dapat mengukapkan satu sifat yang dimiliki oleh pemimpin yang berhasil, melainkan hanya 
sajumlah ciri umum yang mereka miliki. Setiap pemimpin memiliki gaya yang berbeda, apakah demokratis atau otoriter. Tetapi ada satu aspek pemimpin yang menonjol yaitu kewibawaan dan kemimpinan menjadi sistematis dan objektif (Safaria, 2014).

Kemampuan untuk motivasi diri dan orang lain bagi seorang pemimpin mejadi keharusan. Hal ini terungkap dalam pernyataan Keith (Davis, 1953) (Davis, 1985) saat membahas mengenai traits leadership model menyatakan bahwa salah satu sifat seorang pemimpin yang harus tumbuh dan berkembang adalah sifat memotivasi diri untuk berprestasi dan mampu mentransformasikan semangat itu kepada seluruh anggota organisasi yang dipimpinnya. Setiap individu akan memiliki tingkat motivasi kerja yang berbeda sesuai dengan sistem nilai-nilai yang berlaku padanya. Semakin banyak aspek- aspek dalam pekerjaannya yang sesuai dengan keinginannya maka semakin tinggi pula tingkat motivasi kerja yang dimilikinya.

Motivasi hanya diberikan kepada manusia khususnya kepada karyawan atau pengikut. Motivasi mempersoalkan bagaimana cara mendorong gairah kerja karyawan, agar mereka mau bekerja keras dengan memberikan semua kemampuan dan ketrampilannya untuk mewujudkan tujuan instansi atau perusahaan (Hasibuan, 1988) Motivasi kerja yang baik dipengaruhi oleh beberapa faktor, salah satunya dipengaruhi oleh kepemimpinan. Kepemimpinan merupakan inti dari manajemen. Bergeraknya sumber-sumber daya manusia yang tersedia dalam instansi pemerintah disebabkan karena adanya moto penggertak, yaitu seorang pemimpin. Pemimpin merupakan penggerak kegiatan dalam suatu instansi atau perusahaan, untuk mencapai suatu kesuksesan pemimpin memerlukan bantuan dari pihak karyawan agar tercipta kerjasama yang baik dalam menjalankan pekerjaannya (Ma`arif \& Rochmah, 2018; Suprihatin, 2015; Uno, 2008).

Selain kepemimpinan, motivasi kerja juga dipengaruhi oleh lingkungan kerja para karyawan. Lingkungan kerja yang baik menyebabkan karyawan dapat bekerja secara optimal, sedangkan lingkungan kerja yang kurang baik akan menyebabkan pegawai mudah bosan sehingga dalam pencapaian tujuan organisasi tersebut kurang efektif dan akhirnya produktivitas menjadi menurun. Usaha kerjasama antara seorang pemimpin dengan para karyawannya akan berlangsung baik jika ada kemampuan untuk memotivasi orang-orang tersebut ke arah tujuan yang telah ditetapkan. Kemampuan motivasi orang-orang itu merupakan motor penggerak atau daya penggerak yang melebihi kemampuan orang-orang lain itu untuk bekerja menuju terciptanya tujuan karena kepemimpinan merupakan aspek penting. Suatu kerjasama yang sekalipun sudah lengkap dengan orang-orangnya, jelas tujuannya dan sudah ada pula kegiatannya, tanpa adanya suatu kemampuan yang dapat memotivasi mengarahkan dan membimbing pelaksanaanya maka kerjasama tersebut tidak efisien.

Menurut (Stoner et al., 1996) kepemimpinan merupakan suatu proses pengarahan dan pemberian pengaruh pada kegiatan-kegiatan dari sekelompok anggota yang saling berhubungan tugasnya. Perilaku pemimpin pada dasarnya terkait dengan proses pertukaran yang terjadi antara pemimpin dan karyawannya. Jika seseorang berusaha untuk mempengaruhi perilaku orang lain , berarti dia telah terlibat ke dalam aktivitas kepemimpinan. Apabila kepemimpinan tersebut terjadi dalam organisasi tertentu, dan pemimpin tersebut perlu mengembangkan staf dan membangun iklim kerja yang baik sehingga akan menghasilkan tingkat kinerja yang tinggi. Selain itu, gaya kepemimpinan juga perlu dipikirkan oleh seorang pemimpin. Gaya kepemimpinan merupakan suatu norma perilaku yang digunakan, pada saat orang tersebut mencoba untuk mempengaruhi perilaku orang lain supaya berperilaku seperti apa yang diinginkan(Danim, 2003, p. 294).

Motivasi kerja merupakan salah satu unsur penting dalam karyawan sebuah lembaga, artinya motivasi harus dimiliki setiap pegawai. Pegawai dengan motivasi kerja yang baik akan melaksanakan setiap pekerjaan yang diberikan dengan sebaik-baiknya dan mengerahkan seluruh kemampuan yang dimiliki untuk menyelesaikan suatu pekerjaan, seperti yang dikemukakan oleh Robins bahwa "Motivasi adalah kesediaan untuk mengeluarkan tingkat upaya yang tinggi ke arah tujuan organisasi, yang dikondisikan oleh kemampuan upaya itu untuk memenubi sesuatu kebutuhan individual". 
Motivasi kerja yang rendah atau kurang baik akan merugikan lembaga, karena dengan motivasi kerja yang rendah pencapaian tujuan lembaga akan tertunda. Oleh karena itu motivasi kerja merupakan sesuatu yang penting yang harus dimiliki pegawai (Mojavezi \& Tamiz, 2012; Syakroni et al., 2019).

Adanya sebuah organisasi juga membutuhkan seorang leader atau pemimpin. Pemimpin yang akan menciptakan suasana peningkatan motivasi sumber daya manusia yang nyaman bagi setiap instrument dalam Yayasan adalah peranan dari seorang pemimpin yang baik. Bagaimana seorang pemimpin dapat memberikan dorongan positif bagi karyawan-karyawannya untuk mencapai hasil maksimal. Karena kepemimpinan sangat berpengaruh terhadap peningkatan motivasi sumber daya manusia untuk mencapai keberhasilan. Bahkan berkembang tidaknya sebuah organisasi adalah peranan penting dari seorang pemimpin yang dapat mengkondisikan lingkup kerja dan anggotanya untuk mencapai tujuan. Karena pemimpin yang baik adalah mampu mempengaruhi, mengajak, mengatur serta mampu memotivasi dengan kehati-hatian dan tanggung jawab.

\section{METODE PENELITIAN}

Jenis penelitian dalam proposal ini adalah penelitian kualitatif dan penelitian lapangan (field research), karena informasi diperoleh secara langsung dari lapangan, dalam hal ini adalah Pondok Pesantren Amanatul Ummah Mojokerto. Penelitian ini menggunakan penelitian kualitatif, yaitu penelitian yang dilakukan untuk membangun teori dari suatu data, di mana desain dari metode kualitatif tersebut bersifat umum, fleksibel, dan berkembang dalam proses penelitian

Dalam penelitian ini, peneliti menggunakan pendekatan pendekatan dari disiplin ilmu psikologi atau kejiwaan. Dalam perspektif ini, kajian diarahkan untuk menggali aspek psikologis kepemimpinan subjek penelitian dan mengambil pelajaran darinya sesuai tujuan dan manfaat penelitian. Lokasi yang dijadikan tempat penelitian, yaitu Pondok Pesantren Amnatul Ummah Pacet Mojokerto yang beralamat di dusun Paras, desa Kembangbelor, Kec. Pacet, Mojokerto, Jawa Timur 61374.

Subjek penelitian ini adalah Prof. Dr. KH. Asep Saifuddin Chalim. Sedangkan yang menjadi objek penelitian ini adalah gaya kepemimpinan Prof. Dr. KH. Asep Saifuddin Chalim dalam meningkatkan motivasi kerja karyawan dan bagaimana implementasi gaya kepemimpinan Prof. Dr. KH. Asep Saifuddin Chalim dalam meningkatkan motivasi kerja di Ponpes Amnatul Ummah. Untuk mendapatkan data yang relevan, maka penelitian ini menggunakan teknik pengumpulan data, yaitu : 1) Metode Observasi (Pengamatan), 2) Metode Interview (Wawancara) 3) Metode Dokumentasi (Sugiyono, 2008).

Menurut (Taylor et al., 2016) menjelaskan bahwa analisis data kualitatif adalah proses mencari dan menyusun secara sistematis data yang diperoleh dari hasil wawancara, catatan lapangan, dan bahan-bahan lain, sehingga dapat mudah dipahami dan temuannya dapat di informasikan kepada orang lain. Analisis data dilakukan dengan mengorganisasikan data, menjabarkan ke dalam unit-unit, melakukan sintesa, menyusun ke dalam pola,

Analisis data yang digunakan dalam penelitian ini, menurut Miles Huberman yaitu terdiri dari 3 tahap yakni : 1) Reduksi data: Informasi yang diperoleh dari lapangan sangat banyak, oleh karena itu peneliti harus melakukan pencatatan dengan teliti dan rinci. Sama halnya yang ditemukan, semakin lama peneliti terjun ke lapangan, maka jumlah data akan semakin banyak, kompleks dan rumit. Oleh karena itu perlu adanya analisis data melalui reduksi data. ${ }^{1}$ Penyajian Data 
Penarikan Kesimpulan: Dalam analisis data kualitatif menurut Miles dan Huberman adalah penarikan kesimpulan dan verifikasi. Kesimpulan awal yang disajikan masih bersifat sementara, dan akan berubah jika ditemukan bukti yang valid seiring dilakukannya kembalipenelitian lanjutan yang konfirmatif ke lapangan untuk mengumpulkan untuk merumuskan kesimpulaan yang kredibel.

\section{HASIL DAN PEMBAHASAN}

\section{Gaya Kepemimpinan Prof. Dr. Kh. Asep Saifuddin Chalim Dalam Meningkatkan Motivasi Kerja Karyawan Di Pondok Pesantren Amanatul Ummah}

Berdasarkan hasil observasi dan wawancara diperoleh data, bahwa gaya kepemimpinan Kiai Asep di Pondok Pesantren Amanayul Ummah telah tercapai yang di lihat dari beberapa indikatotor. Dengan hasil wawancara dan observasi penelitian berikut antara lain :

\section{Gaya Kepemimpinan Prof. Dr. KH. Asep Saifuddin Chalim}

Figur kepemimpinan Kiai Asep merupakan kunci keberhasilan di lembaga pondok pesantrennya, Kiai sangat berpengaruh dalam perkembangan karyawannya dan kemajuan akademiknya. Faktor yang sangat penting yang harus dimiliki oleh seorang Kiai adalah wibawa atau kharisma jiwa kepememimpinan, sehingga santri, karyawan dan masyarakat dapat meneladani sikap Kiai.

Berdasarkan wawancara dengan informan, diperoleh informasi, bahwa Kiai Asep dalam kepemimpinanya sangat dihormati oleh seluruh warga pesantren maupun bawahan atau karyawannya, figur seorang Kiai yang memiliki kharisma yang dapat memberikan teladan bagi seluruh warga pesantren seperti dalam berprilaku, bertutur kata dan bersikap amat diperhatikan dengan cermat oleh sumber daya manusia di sekitarnya. Seperti yang terlihat pada saat Kiai sedang berjalan di gedung pesantren dan ada seorang santri, santri tersebut langsung menundukan setengah badanya sebagai rasa tadzim seorang santri kepada Kiainya. Selain itu saat Kiai sedang berbicara dengan salah satu karyawannya yakni pengurus. Karyawannya tersebut begitu memperhatikan dengan tawadhu, Kemudian ketika alas kaki Kiai yang berantakan, seorang santri langsung merapikanya dengan posisi siap pakai, di situ terlihat bahwasannya Kiai sangat dihormati oleh santri dan karyawannya.

\section{Memiliki Visi Misi Yang Relevan Dengan Kebutuhan Yang Sesui Dengan Perkembangan Zaman}

Orang tentu saja boleh berbeda pandangannya tentang masa depan Pondok Pesantren Amanatul Ummah, Kiai Asep memiliki visi misi yang jelas dan relevan dengan perkembangan zaman sehingga untuk kemajuan lembaga-lembaga pendidikan yang ada di Pondok Pesantren Amanatul Ummah sangatlah memepengaruhi dalam kemajuan, seperti visi yang terdapat di Pondok Pesantren Amanatul Ummah yaitu : "Terwujudnya manusia yang unggul, utuh, dan berakhlaqul karimah untuk kemuliaan dan kejayaan islam dan kaum muslimin, kemuliaan dan kejayaan seluruh bangsa indonesia dan untuk keberhasilan cita- cita kemerdekaan yaitu terwujudnya kesahjetraan dan tegaknya keadilan bagi seluruh bangsa indonesia tanpa terkecuali". Dan misi sebagai berikut: "Melaksanakan sistem yang berlaku di lembaga pendidikan unggulan amanatul ummah secara ketat, dan bertangung jawab ". 


\section{Memiliki Keterampilan Komunikasi Yang Hebat}

Kiai Asep terlihat hebat di mata karyawannya, santrinya, maupun masyarakat, ketika memiliki keterampilan komuniksi yang luar biasa, hal ini ditandai dengan Kiai Asep sering diundang untuk mengisi seminar mapun tausiah di beberapa acara dan tempat lembaga pendidikan perguruan tinggi. Dan juga Kiai Asep sering mendatangkan pemateri-pemateri hebat nasional maupun internasional ke Pondok Psantren Amanatul Ummah. Menurut Pak Cecep salah satu karyawan Kiai Asep sekaligus keponakan Kiai Asep, bahwa setiap kata-kata Kiai mengandung makna yang menggugah jiwa setiap orang yang mendengarnya untuk dapat mengikuti jejak beliau dalam mengamalkan kebaikan.

\section{Memiliki Sikap Percaya Diri Yang Tinggi}

Kepemimpinannya memiliki prinsip yang kuat dan percaya diri yang tinggi untuk memajukan kemajuan akademik, Kiai Asep merupakan sosok yang tegas dalam mengambil keputusan. Di Pondok Pesantren Amanatul Ummah yang diasuh oleh Kiai Asep memiliki hal tersebut. Di pondok Kiai sangat menjunjung tinggi ilmu agama, ilmu bahasa dan diimbangi dengan ilmu umum. Ilmu agama merupakan hal yang utama untuk kehidupan di dunia dan akhirat. Sehingga Kiai Asep selalu menjunjung tinggi visi misi beliau dan selalu menanamkan karakter yang baik dan sesui keinginan Kiai Asep terhadap santrinya maupun karyawannya. Dan Kiai juga membekali tidak hanya ilmu agama, tetapi juga membekalinya dengan ilmu bahasa, antara lain bahasa inngris dan bahasa Arab, serta dengan ilmu umum, agar bisa mengikuti perkembangan zaman yang beredar di masyarakat. Kiai Asep merupakan sosok yang tegas dan bijaksana dalam mengambil segala keputusan selagi yang dijalankan adalah hal kebaikan.

\section{Memiliki Sikap Tenang Dalam Menghadapi Segala Hal}

Dalam hal ini Kiai Asep juga mempunyai sikap tenang dalam mengahadapi segala, hal baik dari lingkungan eksternal maupun internal. Bahkan Kiai sering mengambil resiko pribadi, serta lebih mendahulukan kepentingan akademik dari pada kepentingan pribadinya. Seperti menghadapi wabah virus corona (Covid-19), seperti diketahui bersama, wabah virus corona telah berdampak luas ke suluruh dunia, termasuk Indonesia, pandemi yang terjadi sejak akhir tahun 2019 tersebut, telah menyerang jutaan orang. Ratusan ribu orang dirawat, sebagian sembuh, dan ribuan lainnya meninggal dunia. Jumlah pasien yang positif terjangkit Covid-19 di Indonesia masih terus bertambah.

Sebagai pengasuh pondok dan tokoh masyarakat, Kiai Asep pun menggunakan segala daya dan pengaruhnya untuk membantu pemerintah. Kiai Asep juga membantu warga masyarakat untuk meringankan beban hidupnya dan Kiai Asep juga membagikan beberapa amalan untuk mencegah terjangkit Covid-19. Yakni : melakukan upaya lahir sebagaimana disosialisasikan banyak pihak, banyak membaca kalimat istigfar, terus meningkatkan ketaqwaan kepada Allah, selalu membaca hauqola saat berada di tempat rawan Covid-19, dan mengamalkan doa qunut di setiap salat wajib.

\section{Gaya Kepemimpinan Prof. Dr. KH. Asep Saifuddin Chalim Dalam Membentuk Motivasi Kerja Karyawan Di Ponpes Amanatul Ummah}

Motivasi merupakan salah satuh aspek yang sangat penting dalam membentu perilaku karyawan, termasuk perilaku kerja. Pentingnya motivasi karena motivasi hal yang meyebabkan, menyalurkan, dan mendukung perilaku manusia, supaya mau kerja giat dan antusias mencapai hasil yang optimal. 
Berdasarkan hasil observasi dan wawancara diperoleh data, bahwa gaya kepemimpinan Kiai Asep dalam membentuk motivasi kerja karyawannya di Pondok Pesantren Amanatul Ummah telah tercapai dengan beberapa indikatotor verifikatif. sebagai hasil wawancara dan observasi penelitian berikut, di antaranya:

\section{Membentuk motivasi dalam memberikan kebutuhan fisiologis karyawan}

Salah satu faktor kepemimpinan Kiai Asep dalam membentuk motivasi karyawannya adalah dengan cara memberikan kebutuhan fisiologis terhadap karyawannya, dalam hal ini Kiai Asep tidak segan-segan mengeluarkan biaya yang cukup banyak untuk perkembangan lembaga pendidikannya, termasuk kebutuhan-kebutuhan fisiologis karyawan.

Kiai Asep memberikan bentuk motivasi kepada karyawannya dalam beberapa bentuk yakni: gaji karyawan, konsumsi karyawan saat ada kegiatan pertemuan, atau menyediakan ruang transit (guesshouse) tempat para karyawan beristirahat sebelum dan setelah ada acara pertemuan.

\section{Membentuk motivasi dalam memberikan kebutuhan rasa aman karyawan}

Setelah kebutuhan fisiologis karyawan terpenuhi, maka akan timbul perasaan untuk perlunya kebutuhan keamanan karyawan. Dalam penerapannya, Kiai Asep memberikan kebutuhan rasa aman terhadap karyawannya dengan cara memberikan amaliyah- amaliyah kepada karyawannya untuk melaksakan sholat malam dan istighotsah dalam menjaga keamanan psikis karyawan dalam membentuk spritualitas karyawan, dan memperkerjakan beberapa security yang ditempatakan di beberapa lembaga yang berada di kawasan Pondok Pesantren Amanatul Ummah, agar keamanan santri, tenaga kependidikan, serta seluruh karyawan Kiai tetap terjaga dari masalah-masalah yang muncul dari luar maupun dari dalam. Kiai Asep juga tak lupa memberikan santunan social kepada karyawannya agar semangat karyawan tetap teraktualisasi dan terjaga.

\section{Membentuk motivasi kebutuhan akan kasih sayang kepada karyawan}

Kebutuhan akan kasih sayang adalah kebutuhan untuk bersosialisasi kepada karyawan diterima dan dihargai di lingkungan Pondok Pesantren Amanatul Ummah, salah satu cara untuk memenuhi kebutuhan ini, Kiai Asep mengadakan pertemuan atau rapat dengan para karyawannya sebanyak 1 bulan 3 kali, bahkan uniknya, Kiai Asep melaksakan pertemuan setiap 1 minggu 2 kali peretemuan untuk mejaga erat silaturahmi antara Kiai Asep dan Karyawannya.

Dalam hasil wawancara kepada Kiai Asep, Kiai Asep mengatakan "bentuk dari motivasi rasa kasih sayang terhadap karyawan adalah komunikasi, saya selalu berkomunikasi dengan karyawan, karena hal tersebut sangat penting apalagi menyangkut masa depan lembaga. "Komunikasi selalu saya lakukan melalui pertemuan-pertemuan rutin antara karyawan, baik saat waktu kerja maupun di luar waktu kerja. Di luar waktu kerja, saya biasanya makan malam dengan beberapa karyawan, dengan begitu saya dapat menyempatkan diri berkomunikasi dengan cara berbeda, lebih rileks dan santai, tanpa ada batasan mana pun antara pemimpin dan karyawan, biasanya saya sering berkomunikasi dengan pak Gatot atau pak Cecep. Dengan cara itu maka hubungan saya dengan karyawan terjalin dengan baik".

\section{Memberikan bentuk motivasi kebutuhan akan pengharagaan terhadap karyawan}

Kebutuhan ini berkaitan dengan reputasi, kebutuhan akan status pengakuan, penghargaan dan pandangan baik dari orang lain. Salah salah satu penghargaan yang diberikan Kiai Asep adalah dengan adanya penghargaan kepada karyawan berupa Umroh, 
Naik Haji, dan memberikan tanggung jawab kepada karyawan untuk memimpin beberapa lembaga pendidikan yang ada di bawah Yayasan Pondok Pesantren Amanatul Ummah.

\section{Kebutuhan akan aktualisasi diri}

Aktualisasi diri adalah kebutuhan dengan menggunakan keterampilan dan potensi untuk mencapai prestasi kerja dan penjenjangan karir karyawan. Pemenuhan kebutuhan ini, Kiai Asep mempunyai kemauan besar dalam aktualisasi diri untuk mencapai visi misi dalam lembaga pendidikan Kiai, maka dari itu Kiai Asep sering kali memberikan fasilitas terhadap karyawannya untuk melaksankan program Kiai Asep dalam berkiprah dalam lembaga maupun di luar lembaga dalam mewujudakan tujuan lembaga pendidikan.

Uraian di atas sesuai dengan teori yang telah disesuaikan oleh peneliti dengan beberapa hasil lapangan antara lain: Dalam penelitian ini telah sesuai dengan teori tentang indikator kepemimpinan dalam sebuah patokan antara lain :

Pengaruh: Serangkaian usaha yang dilakukan oleh seorang pemimpin, dengan menunjukan keteladanan, kewibawaan dan kecakapan, untuk mengerakkan dan mengarahkan karyawan melakukan tugas tugasnya guna mencapai tujuan organisasi atau perusahaan secara efektif dan efisien. Pengaruh yang baik yang diberikan seorang pemimpin kepada karyawan akan membantu pencapaian tujuan lembaga pendidikan. Subjek penelitian telah memiliki indicator ini.

Informasi: Serangkaian usaha yang dilakukan oleh seorang pemimpin untuk memperoleh dan menyampaikan berita atau pesan baik secara langsung maupun tidak langsung kepada karyawannya, sehingga tenaga civitas akademika atau karyawannya mengerti dan dapat melaksanakan tujuan perusahaan secara efektif dan efisien. Informasi harus disampaikan kepada karyawan agar karyawan dapat melaksanakan pekerjaan sesuai tujuan lembaga pendidikan. Subjek penelitian telah memiliki indicator ini.

Pengambilan Keputusan: Serangkaian usaha yang dilakukan oleh seorang pemimpin dalam menentukan strategi lembaga guna mencapai tujuan lembaga secara efektif dan efisien, baik dengan memperhatikan saran dari karyawannya maupun atas keputusan sendiri. Keputusan yang diambil dengan memperhatikan visi dan misi lembaga pendidikan. Subjek penelitian telah memiliki indicator ini.

Memotivasi: Serangkaian usaha yang dilakukan oleh seorang pemimpin untuk dapat memberikan motif atau dorongan, memenuhi harapan dan memberikan penghargaan kepada semua civitas akademika atau karyawannya sehingga semua civitas akedimaka dan semua tenaga kependidikan merasa termotivasi melakukan tugas dengan ikhlas, antusias dan senang hati guna mencapai tujuan lembaga pendidikan secara efektif dan efisien. Subjek penelitian telah memiliki indicator ini.

Karyawan memiliki sasaran kinerja yang tinggi, dan mereka yakin bahwa mereka dapat berkontribusi terhadap keberhasilan dari visi misi itu. Pememimpin mempunyai kekuasaan rasa percaya diri, serta berpendirian dalam keyakinan dan cita-cita dan terbukti sekaligus terverifikasi betapa kepemimpinan Kiai Asep telah mampu memberikan motivasi yang kuat dalam menjalani dan mebangun kinerjanya secara memadai. Suatu kebutuhan otoritataif seorang pemimpin, dalam hal ini Kiai Asep diverifikasi telah memotivasi karyawan serta memberi imbas rasa percaya diri dan pendirian yang kuat pada diri karyawan. Kalimat konklutif yang bisa disampaikan pada observasi penelitian ini adalah "Kepemimpinan Kiai Asep telah memberikan motivasi kuat kepada karyawannya untuk berkinerja tinggi”. 


\section{KESIMPULAN}

Berdasarkan hasi dan analisis pembehasan pada penelitian ini tentang Gaya Kepemimpinan Prof. Dr. KH. Asep Saifuddin Chalim dalam Meningkatkan Motivasi Kerja Karyawan Di Pondok Pesantren Amanatul Ummah, secara keseluran melalui interview, observasi dan dokumentasi, maka dengan demikian penulis menyimpulkan bahwa :

Gaya Kepemimpinan Prof. Dr. KH. Asep Saifuddin Chalim Dalam Meningkatkan Motivasi Kerja Karyawan Di Pondok Pesantren Amanatul Ummah telah tercapai dan bergaya kharismatik, yang dilihat dari empat indikator hasil penelitian yang sesuai dengan teori yang di antaranya adalah sebagai berikut : 1) Memunyai visi misi yang relevan dengan kebutuhan karyawan dan sesuai perkembangan zaman. 2) Mempunyai keterampilan komunikasi yang hebat, terutama dalam mempengaruhi pikiran, perasaan, tingkah laku karyawan, sehingga dapat membangkitkan rasa kagum dari karyawan dan masyarakat sekitar yang mencitrakan ketrampilan komunikasi yang memadai pada diri Kiai Asep dalam kepemimpinannya. 3) Mempunyai sikap tenang dalam menghadapi segala hal dalam menghadapi segala hambatan yang terjad, walaupun harus mempertaruhkan resiko pribadi. 4) Mempunyai sikap percaya diri yang tinggi dalam melakukan hal-hal kebaikan.

Gaya Kepemimpinan Prof. Dr. KH. Asep Saifuddin Chalim dalam Membentuk Motivasi Kerja Karyawan Di Pondok Pesantren Amanatul Ummah telah tercapai bersifat subtitutif (memadai dalam pemenuhan kebutuhan secara motivatif), yang dilihat dari lima indikator hasil penelitian, yang sesuai dengan teori di antaranya: 1) Bentuk motivasi dalam memberikan kebutuhan fisiologis karyawan terpenuhi. 2) Betuk motivasi dalam memberikan kebutuhan rasa aman karyawan terpenuhi. 3) Bentuk motivasi dalam memberikan kebutuhan akan kasih sayang karyawan terpenuhi. 4) Bentuk motivasi dalam memberikan kebutuhan akan penghargaan terhadap karyawan terpenuhi. 4) Bentuk motivasi dalam memberikan kebutuhan aktualisasi diri terhadap karyawan terpenuhi.

\section{DAFTAR PUSTAKA}

Arifin, Z. (2014). Pendidikan islam dalam perspektif filsafat ilmu. Ta'dib, 19(01), 123-142. http://jurnal.radenfatah.ac.id/index.php/tadib/article/view/12

Bahri, S., \& Arafah, N. (2020). Analisis Manajemen SDM Dalam Mengembangkan Strategi Pembelajaran Di Era New Normal. Tafkir: Interdisciplinary Journal of Islamic Education, 1(1), 20-40. https://doi.org/10.31538/tijie.v1i1.2

Danim, S. (2003). Menjadi komunitas pembelajar: Kepemimpinan transformasional dalam komunitas organisasi pembelajaran. Bumi Aksara. https://books.google.co.id/books?id=nO_AAAACAAJ

Danim, S. (2009). Manajemen dan kepemimpinan transformasional kekepalasekolahan: Visi dan strategi sukses era teknologi, situasi krisis, dan internasionalisasi pendidikan. Rineka Cipta.

Davis, K. (1953). Management Communication and the Grapevine. Graduate School of Business Administration, Harvard University.

Davis, K. (1985). Perilaku dalam organisasi edisi 7 jilid 2. Erlangga.

Devi, A. D., \& Subiyantoro, S. (2021). Implementation of Democratic Leadership Style and Transformational Head of Madrasah in Improving The Quality. Nidhomul Haq : Jurnal Manajemen Pendidikan Islam, 6(1), 14-26. https:// doi.org/10.31538/ndh.v6i1.1162

Ezzani, M., \& Brooks, M. (2019). Culturally Relevant Leadership: Advancing Critical Consciousness in American Muslim Students. Educational Administration Quarterly, 55(5), 781-811. https://doi.org/10.1177/0013161X18821358

Hasibuan, J. J. (1988). Proses belajar mengajar: Ketrampilan dasar pengajaran mikro. Remaja Rosdakarya, Bandung. 
Kartiko, A., \& Azzukhrufi, jaya R. (2019). Pengaruh Budaya Organisasi Dan Kompensasi Terhadap Kinerja Pendidik Di Madrasah Aliyah Nahdlatul Ulama Mazro'atul Ulum Paciran. Nidhomul Haq: Jurnal Manajemen Pendidikan Islam, 4(2), 207-226. https://doi.org/10.31538/ndh.v4i2.351

Kartiko, A., Ma`arif, M., Zuana, M. M., Aprilianto, A., \& Rusydi, I. (2020, February 10). The Influence of Leadership, Compensation on Nurses' Performance in the Mother and Child Hospital Fatimah' Lamongan. Proceedings of the 2nd International Conference on Economics, Business, and Government Challenges, EBGC 2019, 3 October, UPN ‘ Veteran’ East Java, Surabaya, Indonesia, Indonesia. http://dx.doi.org/10.4108/eai.3-10-2019.2291913

Krisbiyanto, A. (2019). Efektifitas Kepemimpinan Kepala Madrasah terhadap Mutu Pendidikan MTsN 2 Mojokerto. Nidhomul Haq: Jurnal Manajemen Pendidikan Islam, 4(1), 52-69. https://doi.org/10.31538/ndh.v4i1.182

Ma`arif, M. A., \& Rochmah, S. (2018). Target Hafalan sebagai Motivasi Belajar dalam Membentuk Karakter di Lingkungan Pesantren. Muróbbî: Jurnal Ilmu Pendidikan, 2(1), 105127. http://jurnal.iaibafa.ac.id/index.php/murobbi/article/view/127

Mojavezi, A., \& Tamiz, M. P. (2012). The Impact of Teacher Self-efficacy on the Students' Motivation and Achievement. Theory \& Practice in Language Studies, 2(3).

Safaria, T. (2014). Kepemimpinan. graha ilmu. https://openlibrary.telkomuniversity.ac.id/pustaka/38467/kepemimpinan.html

Stoner, A. F., Freeman, R. E., \& Gilbert, D. R. (1996). Manajemen Edisi Bahasa Indonesia. PT. Prenballindo. Jakarta.

Sugiyono. (2008). Metode penelitian pendidikan: (Pendekatan kuantitatif, kualitatif dan R \& D). Alfabeta.

Suprihatin, S. (2015). Upaya Guru Dalam Meningkatkan Motivasi Belajar Siswa. Promosi (Jurnal Pendidikan Ekonomi), 3(1). https://doi.org/10.24127/ja.v3i1.144

Syakroni, A., Zamroni, Muali, C., Baharun, H., Sunarto, M. Z., Musthofa, B., \& Wijaya, M. (2019). Motivation And Learning Outcomes Through The Internet Of Things\$mathsemicolon\$ Learning In Pesantren. Journal of Physics: Conference Series, 1363, 012084. https://doi.org/10.1088/1742-6596/1363/1/012084

Taylor, S. J., Bogdan, R., \& DeVault, M. L. (2016). Introduction to qualitative research methods: $A$ guidebook and resource (Fourth edition). John Wiley \& Sons, Inc.

Uno, H. B. (2008). Teori Motivasi \& Pengukurannya: Kajian \& Analisis Di Bidang Pendidikan.

Yunus, A. L. (2009). Leadership model: Konsep dasar, dimensi kinerja, dan gaya kepemimpinan. UINMaliki Press. http:/ / repository.uin-malang.ac.id/1580/

Zuhairini (Ed.). (1992). Filsafat pendidikan Islam (Cet. 1). Bumi Aksara. 